=短 報 $=$

\title{
遺伝子塩基配列を指標とした 食品由来Fusarium 属分離株の同定
}

\author{
渡辺麻衣子*1 ・ 小沼ルミ*2・米澤隆弘*3 ${ }^{*}$ 瓦田研介*2 \\ 小西良子*1 $\cdot$ 鎌田洋一 ${ }^{* 1}$ \\ $(* 1$ 国立医薬品食品衛生研究所, \\ *2 地方独立行政法人東京都産業技術研究センター, \\ *3 復旦大学) \\ （受付：平成 24 年 2 月 12 日） \\ (受理：平成 24 年 9 月 27 日)
}

\section{Identification of Food-Borne Isolates of the Genus Fusarium Based on the Nucleotide Sequence Homology}

\author{
Maiko Watanabe ${ }^{* 1,}{ }^{\dagger}$, Rumi Konuma ${ }^{* 2}$, Takahiro YoneZawa*2, \\ Kensuke Kawarada ${ }^{* 2}$, Yoshiko Sugita-Konishi ${ }^{* 1}$ \\ and Yoichi Kamata ${ }^{* 1}$ \\ (*1 National Institute of Health Sciences, National Institute of Health Sciences, \\ Kamiyoga, Setagaya-ku, Tokyo $158-8501 ;{ }^{\dagger}$ Corresponding author) \\ (*2 Tokyo Metropolitan Industrial Technology Research Institute, Aomi, Koto-ku, Tokyo 135-0064) \\ (*3 Fudan University, Handan Rd. 200433, Shanghai)
}

In this study, we aimed to evaluate the usability of some genetic markers which were previously reported the capability to identify Fusarium isolates based on barcording with nucleotide sequences, and to clear up the questionable points of application for actual isolates. We constructed a local database containing 46 reference sequences of Fusarium strains already-identified, and sequenced six genetic regions of 19 food-borne Fusarium isolates. And then, the nucleotide sequence homologies of each genetic region were calculated pairwisely between an isolate and a reference strain. The $18 \mathrm{~S}$ rDNA, $5.8 \mathrm{~S}$ rDNA, 28S rDNA and ITS1 sequences leaded to the accurate identification of only three to 13 isolates, respectively, because of perfect matches to sequences of more than two species of reference strains, or mis-identification. The lys 2 sequences leaded to the accurate identification of several isolates not identified by these four regions. However, other five isolates could not be identified because of non-amplification of lys 2 by PCR. The $\beta$-tub sequences leaded to the accurate identification of all tested-isolates. Thus, the $\beta$-tub is more useful genetic marker for identifying Fusarium isolates in a wide range than other five loci including lys2.

Key words: Fusarium, beta-Tubulin, Nucleotide sequence homology

\footnotetext{
$\dagger$ 連絡先

*1 俨158-8501 東京都世田谷区上用賀 1-18-1

*2 函135-0064 東京都江東区青海 2-4-10

*3 上海市楊浦区邯鄲路 220 号
}

\author{
緒言 \\ Fusarium 属菌は, 植物の病原体や土潩微生物として \\ 広く分布する真菌であり, 多くの農産物からしばしば検 \\ 出されることが知られる7)。 また, Fusarium属菌はマ \\ イコトキシンの産生菌としても知られ, 過去, 日本を含
}


む世界各地で, trichothecene類やfumonisin類に代表さ れるFusarium属菌が産生したマイコトキシンに污染さ れた食品または飼料を摂食したことによるヒトおよび家 畜の中毒事故が報告されている7). 以上の観点から, Fusarium 属菌は食品微生物学上たいへん重要な真菌で ある。

Fusarium 属菌の同定は, 胞子の形態, 分生子形成様 式, 寒天培地上の集落の性状など主に形態学的指標を用 いて行われてきた ${ }^{4)}$ が, Fusarium 属菌の形態学的同定 は，力ビの中でも特に困難であることが知られている。 その理由の一つとして, 菌種内の形態的・分子生物学的 多様性が大きく，同種と異種の境界が重なる場合が多い ことが挙げられる。そのため，一つの菌種において複数 の種内集団が認識されることもあり，また，これらの集 団が複数菌種にわたり，それらを一つの種複合体(species complex)として認識することがある5).このような 菌種・種内集団の識別は特に困難であることが多い。一 方で, F. equiseti/semitectum species complex, F. oxysporum species complex, $F$. solani species complex, Gibberella fujikuroi species complexなどが多種類の食 品から高頻度で検出されることが知られており ${ }^{7)}$, species complex形成菌種を識別できる同定手法についての 検討は重要な課題である.

そのような背景から, 近年は, Fusarium属菌の同定 の場においても，遺伝子塩基配列の解析をはじめとした 分子生物学的手法が盛んに用いられ, 強力な同定ツール となっている. 複数遺伝子の塩基配列を指標とした系統 解析をもとにした同定 ${ }^{1,5)}$ など多数の報告がある。さら に，系統解析を伴わない配列比較による簡便な手法とし て, 遺伝子塩基配列のホモロジー検索が用いられること も非常に多い.Fusarium属菌の同定のためには，複数 遺伝子塩基配列データベースおよびBLAST 検索システ ム「Fusarium-ID」がウェブ上で公開され，運用されて いる6). 本システム上では, elongation factor $1 \alpha$ 遺伝子 配列登録が主となっている一方で, 菌種間の系統関係と よく相関することが報告され，Fusarium属菌を含む真 菌全体において最も使用頻度の高いマーカー遺伝子の一 つである rRNA遺伝子 $(\mathrm{rDNA})$ 関連遺伝子群 ${ }^{2)}$ および $\beta$-チューブリン遺伝子 $(\beta-t u b)^{1)}$ については, 現在のとこ ろ収録されている菌種に偏りが見られ，網羅されてはい ない.

Watanabe らは，六つの遺伝子座の塩基配列がホモロ ジーを指標としたFusarium 属菌同定のために適当な情 報を有するか否かについて評価したところ，最も塩基置 換速度が速く正確な同定に適したマーカーとなり得るの は，アミノアジピン酸還元酵素遺伝子(lys2)であること を報告した ${ }^{10)}$. しかし，この検討においては，それぞれ の菌種について用いられた菌株数にかぎりがあり，実際 に分離頻度が高い菌種の種内集団を網羅していない可能 性がある。よって，筆者らによって今後の課題としてす
でに言及されているとおり，評価対象となった遺伝子 が，実際の分離株の同定に適用された際に，想定された 十分な同定精度を発揮できるか否かを検討する必要があ る.

本研究では, 食品由来のFusarium 属菌分離株を対象 として, 理論的にマーカーとして適していることが示唆 された遺伝子を用いて，塩基配列ホモロジーを指標とし た同定を行ったささらに，その結果明らかとなった実際 の同定の場における問題点とその改善策について考察し たので, これらを報告する。

\section{材料および方法}

\section{1. ローカル・データベースの作製}

遺伝子塩基配列のホモロジー検索を行う際の比較対象 菌株（リファレンス菌株）の遺伝子塩基配列を収録した ローカル・データベースを作製した。リファレンス菌株 としては, Fusarium属菌について現在広く用いられて いる形態学的指標による分類体系 ${ }^{4)}$ を参照して, Fusari$u m$ 属菌全体から 21 菌種を選択した。これらの菌種につ いて，正確に同定されている菌株に限定するために，分 譲機関保存株から合計 44 菌株を供試した(Table 1)。対 象の遺伝子座としては, $18 \mathrm{~S}$ rDNA, 5.8S rDNA, internal spacer region 1 (ITS1), 28S rDNA D1/D2 領域, $\beta$-tub およびlys2を選択し, 各リファレンス菌株について, GenBankから登録配列の収集を行った(Table 1).

\section{2. 食品由来Fusarium 属菌株の分離と形態学的同定} 遺伝子塩基配列のホモロジーを指標とした同定対象と して, 食品からFusarium 属菌19菌株を分離収集し, 供 試した(Table 2). 食品からの菌株分離手法は, Pitt と Hockingの方法 ${ }^{7)}$ を参照して行った。供試菌株につい て, 単胞子分離法 ${ }^{4)} に よ る$ 再分離を行った後に, 遺伝子 塩基配列のホモロジーを指標とした同定の結果と比較す るために, あらかじめ, Nelsonらの方法 ${ }^{4)}$ を参照して形 態学的手法による同定を行った。

\section{DNA 抽出と遺伝子塩基配列の決定}

以前筆者らが報告した結果 ${ }^{9)}$ を参照し, potato dextrose broth (PDB; Difco) で培養し得られた菌体を用い, ビーズ破砕を併用したSDS法によってDNAを抽出し た。

PCR 反応およびシークエンス反応には，以前筆者ら が報告した ${ }^{10)}$ プライマーおよび反応条件を用いた。 PCR反応は TaKaRa Ex Taq (タカラバイオ)を, シーク エンス反応はBigDye Terminators v 3.1 Cycle Sequencing Kit (Applied Biosystems)をそれぞれ用いて行った.

\section{4. 遺伝子塩基配列を指標としたFusarium 属菌分離} 株の同定

作製したローカル・データベースに対して，各分離株 の遺伝子塩基配列との1対1のホモロジー検索を行った. 本研究では，各分離株において，最もホモロジーが高 かったリファレンス菌株のみを参照し，各分離株の同定を 
Table 1. Refference sequences of the genus Fusarium used in this study

\begin{tabular}{|c|c|c|c|c|c|c|c|}
\hline \multirow{2}{*}{$\begin{array}{l}\text { Species in tradittional } \\
\text { taxonomic system }\end{array}$} & \multirow{2}{*}{ Collection No. } & \multicolumn{6}{|c|}{ GenBank accession No. } \\
\hline & & $18 \mathrm{~S}$ rDNA & ITS1 & $5.8 \mathrm{~S} \mathrm{rDNA}$ & $28 \mathrm{~S}$ rDNA & $\beta-t u b$ & lys 2 \\
\hline \multirow[t]{2}{*}{ F. acuminatum } & $\mathrm{CBS}^{\mathrm{d}} 485.94$ & AB586907 & AB587001 & AB587001 & AB587001 & AB587049 & AB586952 \\
\hline & MAFF $^{e} 236716$ & AB586908 & AB587002 & AB587002 & AB587002 & AB587050 & AB586953 \\
\hline \multirow[t]{2}{*}{ F. avenaceum } & ATCC $200255^{\mathrm{f}}$ (Type strain) & AB586921 & AB587015 & AB587015 & AB587015 & AB587063 & AB586964 \\
\hline & MAFF 239206 & AB586922 & AB587016 & AB587016 & AB587016 & AB587064 & AB586965 \\
\hline \multirow[t]{2}{*}{ F. decemcellulare } & MAFF 238421 & AB586923 & AB587017 & AB587017 & AB587017 & AB587065 & AB586966 \\
\hline & MAFF 238422 & AB586924 & AB587018 & AB587018 & AB587018 & AB587066 & AB586967 \\
\hline \multirow[t]{2}{*}{ F. dimerum } & CBS 632.76 (Neotype strain) & AB586901 & AB586995 & AB586995 & AB586995 & AB587043 & AB586947 \\
\hline & MAFF 237465 & AB586902 & AB586996 & AB586996 & AB586996 & AB587044 & AB586948 \\
\hline \multirow[t]{2}{*}{ F. equiseti ${ }^{\mathrm{b}}$} & MAFF 236434 & AB586905 & AB586999 & AB586999 & AB586999 & AB587047 & AB586950 \\
\hline & MAFF 236723 & AB586906 & AB587000 & AB587000 & AB587000 & AB587048 & AB586951 \\
\hline \multirow[t]{2}{*}{ F. graminearum } & MAFF 240264 & AB586898 & AB586991 & AB586991 & AB586991 & AB587039 & AB586943 \\
\hline & MAFF 240270 & AB586992 & AB586992 & AB586992 & AB586992 & AB587040 & AB586944 \\
\hline \multirow[t]{2}{*}{ F. larvarum } & CBS 169.30 & AB586891 & AB586984 & AB586984 & AB586984 & AB587032 & - \\
\hline & CBS 638.76 (Isotype strain) & AB586892 & AB586985 & AB586985 & AB586985 & AB587033 & - \\
\hline \multirow[t]{2}{*}{ F. lateritium } & MAFF 235344 & AB586910 & AB587004 & AB587004 & AB587004 & AB587052 & AB586954 \\
\hline & MAFF 840045 & AB586911 & AB587005 & AB587005 & AB587005 & AB587053 & AB586955 \\
\hline \multirow[t]{2}{*}{ F. moniliforme $e^{c}$} & CBS 576.78 (Epitype strain) & AB586916 & AB587010 & AB587010 & AB587010 & AB587058 & AB586960 \\
\hline & CBS 100312 & AB586917 & AB587011 & AB587011 & AB587011 & AB587059 & AB586961 \\
\hline \multirow[t]{2}{*}{ F. merismoides } & CBS 634.76 (Type strain) & AB586903 & AB586997 & AB586997 & AB586997 & AB587045 & AB586949 \\
\hline & MAFF 236504 & AB586904 & AB586998 & AB586998 & AB586998 & AB587046 & - \\
\hline \multirow[t]{2}{*}{$F$. nivale } & CBS 116205 (Isotype strain) & AB586893 & AB586986 & AB586986 & AB586986 & AB587034 & AB586938 \\
\hline & MAFF 236681 & AB586894 & AB586987 & AB586987 & AB586987 & AB587035 & AB586939 \\
\hline \multirow[t]{2}{*}{ F. oxysporum } & MAFF 240304 & AB586899 & AB586993 & AB586993 & AB586993 & AB587041 & AB586945 \\
\hline & MAFF 240321 & AB586900 & AB586994 & AB586994 & AB586994 & AB587042 & AB586946 \\
\hline \multirow[t]{2}{*}{ F. poae } & FRC T-0796 & AB586930 & AB586983 & AB586983 & AB586983 & AB587072 & AB586973 \\
\hline & MAFF 305947 & AB586931 & AB587024 & AB587024 & AB587024 & AB587073 & AB586974 \\
\hline \multirow[t]{3}{*}{ F. proliferatum ${ }^{c}$} & CBS 216.76 (Type strain) & AB586912 & AB587006 & AB587006 & AB587006 & AB587054 & AB586956 \\
\hline & MAFF 238035 & AB586913 & AB587007 & AB587007 & AB587007 & AB587055 & AB586957 \\
\hline & MAFF 237651 & AB725617 & AB725616 & AB725616 & AB725616 & AB725614 & AB725615 \\
\hline F. semitectum ${ }^{\mathrm{b}}$ & MAFF 236521 & AB586895 & AB586988 & AB586988 & AB586988 & AB587036 & AB586940 \\
\hline \multirow[t]{3}{*}{ F. solani } & MAFF 238538 & AB586919 & AB587013 & AB587013 & AB587013 & AB587061 & AB586963 \\
\hline & MAFF 239038 & AB586920 & AB587014 & AB587014 & AB587014 & AB587062 & - \\
\hline & $\mathrm{NBRC}^{\mathrm{g}} 8505$ & AB674259 & AB674260 & AB674260 & AB674260 & AB674261 & AB586981 \\
\hline \multirow[t]{3}{*}{ F. sporotrichioides } & ATCC 34914 & AB586932 & AB587025 & AB587025 & AB587025 & AB587074 & AB586975 \\
\hline & CBS 119839 & AB586933 & AB587026 & AB587026 & AB587026 & AB587075 & AB586976 \\
\hline & MAFF 236639 & AB586934 & AB587027 & AB587027 & AB587027 & AB587076 & AB586977 \\
\hline \multirow[t]{2}{*}{ F. subglutinans ${ }^{c}$} & ATCC 38016 & AB586914 & AB587008 & AB587008 & AB587008 & AB587056 & AB586958 \\
\hline & MAFF 235376 & AB586915 & AB587009 & AB587009 & AB587009 & AB587057 & AB586959 \\
\hline \multirow[t]{2}{*}{ F. tricinctum } & ATCC 38183 (Type strain) & AB586935 & AB587028 & AB587028 & AB587028 & AB587077 & AB586978 \\
\hline & MAFF 235551 & AB586937 & AB587030 & AB587030 & AB587030 & AB587079 & AB586980 \\
\hline \multirow[t]{2}{*}{ F. kyushuense } & MAFF 237645 (Ex holotype strain) & AB586925 & AB587019 & AB587019 & AB587019 & AB587067 & AB586968 \\
\hline & NRRL $^{\text {h }} 6490$ (Type strain) & AB586926 & AB587020 & AB587020 & AB587020 & AB587068 & AB586969 \\
\hline F. langsethiae & CBS 113234 (Holotype strain) & AB586927 & AB587021 & AB587021 & AB587021 & AB587069 & AB586970 \\
\hline & FRC ${ }^{\mathrm{i}} \mathrm{T}-1000$ & AB586929 & AB587023 & AB587023 & AB587023 & AB587071 & AB586972 \\
\hline
\end{tabular}

${ }^{a}$ Nelson, Toussoun, and Marasas, 1983. Fusarium species-An Illustrated Manual for Identification.

b This species belongs to $F$. incarnatum $/ F$. equiseti species complex.

${ }^{c}$ This species belongs to Gibberella fujikuroi species complex.

${ }^{\mathrm{d}}$ Centraalbureau voor Schimmelcultures.

${ }^{\mathrm{e}}$ Ministry of Agriculture, Forestry and Fisheries.

${ }^{\mathrm{f}}$ American Type Culture Collection.

${ }^{g}$ National Institute of Technology and Evaluation, Biological Resource Center.

${ }^{\mathrm{h}}$ Agricultural Research Service Culture Collection in United states Department of Agriculture.

${ }^{i}$ Fusarium Research Center in The Pennsylvania State University.

行った. 5.8S rDNA, ITS1領域, 5.8S rDNA, 28S rDNA D1/D2 領域， $\beta$-tubおよびlys2でそれぞれ493, 136, 159, 466, 586, 560塩基長の塩基配列を解析に用いた。 マルチ プルアライメントおよびホモロジー検索は, Mega ver. 4.18) を用いて行った.

\section{結果および考察}

形態学的指標および塩基配列のホモロジー検索の結果
に基づく食品由来分離株の同定結果をTable 3 に示し た。本表では, 遺伝子ごとに各分離株に対してのホモロ ジーが高かったリファレンス菌株をリストアップした。 本表を見ると, 必ずしも上位から 1 菌種が並ぶとはかぎ らず，時には複数種が入れ子状に並ぶ結果となった。こ のような現象は, Fusarium属菌の遺伝子塩基配列ホモ ロジー検索を行う場合にしばしば見られる。分子系統学 的な解析結果によると, 多くのFusarium 属菌が, 単系 
Table 2. The sources of isolates used in this study

\begin{tabular}{lc}
\hline \multicolumn{1}{c}{ Source } & Strain No. \\
\hline Apple & Ap-1 \\
Banana & Ba-1, Ba-2, Ba-3, Ba-4 \\
Cherry & Ch-1 \\
Corn & Co-1, Co-2 \\
Eggplant & Eg-1 \\
Grain mix & Gmi-1 \\
Grape & Gr-1 \\
Green soybean & So-1 \\
Japanese pear & Jp-1 \\
Oats & Oa-1, Oa-2 \\
Potato & Po-1 \\
Satsuma mandarin & Ma-1, Ma-2 \\
Tomato & To-1 \\
Total isolate No. & 19 \\
\hline
\end{tabular}

統群ではなく側系統群または多系統群となる ${ }^{1,5,11)}$ こと が知られている，このことから，正確に同定されている リファレンス菌株のみが収録されているデータベースを 用いているかぎりにおいては，入れ子状のホモロジー検 索結果を示す原因は，菌種間の系統関係が原因の一つで あると考えられる。そこで本研究では, 各分離株におい て，最も上部にリストアップされたリファレンス菌株の みを参照し同定を行うこととした。

18S rDNA, 5.8S rDNA では, 供試した分離株のうち, F. nivaleまたは F. solani と同定されたBa-1, Gmi-1およ びSo-1については同定が可能であったが，これら 3 菌株 以外の 16 菌株において, 100.0\%のホモロジーを示した リファレンス菌株が複数の菌種にわたり, 同定が不可能 であった(Table 3). 両遺伝子座は, 解析対象とした 6 遺 伝子座の中では塩基置換速度が遅いことが以前筆者らが 報告した結果において示されており ${ }^{10)}$ ，本研究の結果は これと一致した。

28S rDNA D1/D2領域では，上述の $18 \mathrm{~S}$ rDNAおお び5.8S rDNA で同定可能であった 3 菌株に加えて，菌株 Ap-1, Ba-1, Ba-2, Co-1, Co-2, Oa-1, Po-1 およびTo-1につ いては同定が可能であった (Table 3). しかし，その他 の9分離株については, 100.0\%のホモロジーを示したリ ファレンス菌株が複数の菌種にわたり，同定が不可能で あった. 同定が可能であった菌種の内訳を見ると, $F$. nivale または F. solani のほかに, F. oxysporum, $F$. subglutinans および F. verticillioides であれば必ず同定 できていたが, F. proliferatum は1菌株のみで同定が可 能であり，F. equiseti, F. semitectum, F. tricinctum お よび F. sporotrichioides は1菌株も同定できていなかっ た。これら同定が不可能であった菌種はspecies complexを形成する菌種の一つであることが示唆されてお $り^{3,5,11)}$, 菌種の区別が困難な互いにごく近縁な菌種が 存在する。本遺伝子座は, species complexに属するす べての菌種間の差異を十分に識別できるほどの配列の特 異性が蓄積していなかったものと考えられた。 このこと
は，本遺伝子座の塩基置換速度が比較的遅いという以前筆 者らが報告した結果と一致した ${ }^{10)}$.

ITS1では，上述の 28S rDNA D1/D2 領域で同定可能 であった分離菌株のほかに，菌株Ba-4, Gr-1, Jp-1 Ma-1 およびOa-2の同定が可能であった(Table 3). しかし一 方で，Co-1およびOa-1については，28S rDNA D1/D2 領域で同定が可能であったのに対し, ITS1では同定で きなかった，その他の4分離株については，100.0\%のホ モロジーを示したリファレンス菌株が複数の菌種にわた り，候補を 1 菌種に絞ることが不可能であった。同定が 可能であった菌種の内訳を見ると，28S rDNA D1/D2 領域の場合と比較して, さらにF. proliferatum および $F$. semitectumであれば必ず同定可能となったが, 逆にF. verticillioidesである菌株は 1 株も同定できないという違 いが認められた. F. equiseti, F. tricinctumおよびF. sporotrichioidesは, 28S rDNA D1/D2領域の場合と同 様に 1 菌株も同定できていなかった。 以前, 筆者ら ${ }^{10)}$ は, Fusarium 属菌系統樹のすべての枝長を足し合わせ ることによってFusarium 属菌に平均的な塩基置換速度 を算出し, ITS1は28S rDNA D1/D2領域よりも塩基置 換速度が速く同定に適していることを示唆した。 F. proliferatumおよびF. semitectumについては，28S rDNA D1/D2 領域では不可能であった菌種でも同定が可能と なったことから，以前の筆者らの研究と本研究の結果は 一致した。しかし，F. verticillioidesについては，それ と反する結果となった。 これは，F. verticillioidesの系 統においては, ITS1の塩基置換速度はFusarium属菌全 体の傾向と逆転し，28S rDNA D1/D2領域よりも遅 かったためと考えられる。また，ITS1で菌株Ma-2の同 定を試みた際には，F. semitectum MAFF236521 と最も ホモロジーが高いことからF. semitectumと同定され た。しかし, 形態学的手法による同定結果からは, 菌株 Ma-2 は小型分生子を多量に産出すること, 分生子形成 様式は monophialideのみであるなどの特徵を有し, $F$. semitectum は明確に否定され，F. equisetiと同定され た.さらに, $\beta$-tubおよびlys2の示すホモロジーによっ ても菌株 Ma-2 はF. equiseti と同定された。これらの同 定結果を総合的に判断すると, 本菌株はF. equisetiであ り, ITS1はこの場合誤同定を起こしたものと考えられ た. ITS1をF. equisetiおよびF. semitectum 分離株の同 定に用いる際には注意が必要である。

lys2では，PCRで遺伝子増幅が見られシークエンスの 決定が可能であれば，すべての菌株について候補を 1 菌 種に絞ることが可能であった(Table 3). さらに，この 場合，Ch-1 およびTo-1 を除きPCRで遺伝子の増幅が認 められたすべての菌株において6遺伝子中でホモロジー 1 位と 2 位との差が最も大きく, 塩基置換速度が最も速 い遺伝子であるとするWatanabe らの研究結果 ${ }^{10)}$ と一致 した。シークエンスを決定することが可能でさえあれ ば，塩基配列の特異性を認識しやすい同定に適したマー 
Table 3. Identification of candidate species of Fusaium isolates based on mophological methods and nucleotide sequence homologies

\begin{tabular}{|c|c|c|c|c|c|c|c|c|c|}
\hline \multirow{2}{*}{ Isolate } & \multirow{2}{*}{$\begin{array}{l}\text { Identification } \\
\text { based on } \\
\text { morphological } \\
\text { methods }^{\mathrm{a}}\end{array}$} & \multirow{2}{*}{$\begin{array}{c}\text { Identification } \\
\text { based on } \\
\text { nucleotide sequence } \\
\text { homology }\end{array}$} & \multicolumn{7}{|c|}{ Nucleotide sequence homology (\%) } \\
\hline & & & Reference strain & $\begin{array}{l}18 \mathrm{~S} \\
\mathrm{rDNA}\end{array}$ & ITS1 & $\begin{array}{l}5.8 \mathrm{~S} \\
\mathrm{rDNA}\end{array}$ & $\begin{array}{l}28 \mathrm{~S} \\
\mathrm{rDNA}\end{array}$ & $\beta-t u b$ & lys 2 \\
\hline \multirow{3}{*}{ Ap-1 } & \multirow{3}{*}{ F. oxysporum } & \multirow{3}{*}{$\begin{array}{l}\text { ITS1, 28S rDNA, } \\
\quad \beta \text {-tub, lys } 2 \\
\rightarrow \text { F. oxysporum }\end{array}$} & $\begin{array}{l}\text { F. oxysporum } \\
\text { MAFF } 240304\end{array}$ & 100.00 & 100.00 & 100.00 & 99.78 & 98.64 & 96.72 \\
\hline & & & $\begin{array}{l}\text { F. oxysporum } \\
\text { MAFF } 240321\end{array}$ & 100.00 & 100.00 & 100.00 & 99.78 & 98.64 & 96.72 \\
\hline & & & $\begin{array}{l}\text { F. proliferatum } \\
\text { (F. phylophilum) } \\
\text { CBS216.76 }\end{array}$ & 100.00 & 99.17 & 100.00 & 99.35 & 98.46 & 96.23 \\
\hline \multirow{4}{*}{$\mathrm{Ba}-1$} & \multirow{4}{*}{ F. solani } & \multirow{4}{*}{$\begin{array}{l}28 S \text { rDNA, } \\
\beta \text {-tub, lys } 2 \\
\rightarrow F . \text { solani }\end{array}$} & $\begin{array}{c}\text { F. solani } \\
\text { MAFF } 238538\end{array}$ & 100.00 & 97.54 & 100.00 & 100.00 & 98.46 & - \\
\hline & & & $\begin{array}{c}F . \text { solani } \\
\text { NBRC } 8505\end{array}$ & 100.00 & 94.22 & 100.00 & 99.14 & 97.95 & - \\
\hline & & & $\begin{array}{c}\text { F. solani } \\
\text { MAFF239038 }\end{array}$ & 99.39 & 90.08 & 98.11 & 98.27 & 93.69 & - \\
\hline & & & $\begin{array}{c}\text { F. decemcellulare } \\
\text { MAFF238421 }\end{array}$ & 99.80 & 71.90 & 98.74 & 97.19 & 92.83 & \\
\hline \multirow{4}{*}{ Ba-2 } & \multirow{4}{*}{ F. subglutinans } & \multirow{4}{*}{$\begin{aligned} & 28 S \text { rDNA, } \\
& \beta \text {-tub, lys } 2 \\
\rightarrow & \text { F. subglutinans } \\
& (\text { F. sacchari })\end{aligned}$} & $\begin{array}{l}\text { F. subglutinans } \\
(\text { F. sacchari) } \\
\text { MAFF } 235376\end{array}$ & 100.00 & 100.00 & 100.00 & 100.00 & 100.00 & 99.82 \\
\hline & & & $\begin{array}{c}\text { F. subglutinans } \\
\left(F . \text { subglutinans }^{\mathrm{c}}\right) \\
\text { ATCC } 38016\end{array}$ & 100.00 & 99.17 & 100.00 & 100.00 & 95.90 & 94.35 \\
\hline & & & $\begin{array}{l}\text { F. oxysporum } \\
\text { MAFF240304 }\end{array}$ & 100.00 & 98.33 & 100.00 & 99.35 & 97.27 & 94.35 \\
\hline & & & $\begin{array}{l}\text { F. oxysporum } \\
\text { MAFF } 240321\end{array}$ & 100.00 & 98.33 & 100.00 & 99.35 & 97.27 & 94.35 \\
\hline \multirow{3}{*}{ Ba-3 } & \multirow{3}{*}{ F. semitectum } & \multirow{3}{*}{$\begin{array}{l}\text { ITS } 1, \beta \text {-tub, lys } 2 \\
\rightarrow \text { semitectum }\end{array}$} & $\begin{array}{l}\text { F. semitectum } \\
\text { MAFF } 236521\end{array}$ & 100.00 & 100.00 & 100.00 & 100.00 & 99.83 & 90.37 \\
\hline & & & $\begin{array}{c}\text { F. equiseti } \\
\text { MAFF236434 }\end{array}$ & 100.00 & 99.17 & 100.00 & 100.00 & 98.98 & 92.01 \\
\hline & & & $\begin{array}{c}\text { F. equiseti } \\
\text { MAFF236723 }\end{array}$ & 100.00 & 99.17 & 98.73 & 100.00 & 98.46 & 90.98 \\
\hline \multirow{5}{*}{ Ba-4 } & \multirow{5}{*}{ F. proliferatum ${ }^{\mathrm{b}}$} & \multirow{5}{*}{$\begin{array}{c}\quad b \text {-tub, lys } 2 \\
\rightarrow F . \text { proliferatum }\end{array}$} & $\begin{array}{c}F . \text { proliferatum } \\
\left(F . \text { proliferatum }{ }^{c}\right) \\
\text { MAFF } 238035\end{array}$ & 100.00 & 100.00 & 100.00 & 100.00 & 100.00 & 100.00 \\
\hline & & & $\begin{array}{l}\text { F. proliferatum } \\
\text { (F. fujikuroi) } \\
\text { MAFF } 237651\end{array}$ & 100.00 & 100.00 & 100.00 & 100.00 & 99.49 & 98.93 \\
\hline & & & $\begin{array}{c}\text { F. proliferatum } \\
\text { (F. phyllophilum }) \\
\text { CBS } 216.76\end{array}$ & 100.00 & 100.00 & 100.00 & 99.57 & 97.10 & 97.10 \\
\hline & & & $\begin{array}{c}\text { F. subglutinans } \\
(\text { F. sacchari }) \\
\text { MAFF } 235376\end{array}$ & 100.00 & 99.17 & 100.00 & 100.00 & 96.76 & 97.32 \\
\hline & & & $\begin{array}{l}\text { F. oxysporum } \\
\text { MAFF240304 }\end{array}$ & 100.00 & 99.17 & 100.00 & 99.35 & 96.93 & 94.72 \\
\hline
\end{tabular}


Table 3. Continued

\begin{tabular}{|c|c|c|c|c|c|c|c|c|c|}
\hline \multirow{2}{*}{ Isolate } & \multirow{2}{*}{$\begin{array}{l}\text { Identification } \\
\text { based on } \\
\text { morphological } \\
\text { methods }^{\text {a }}\end{array}$} & \multirow{2}{*}{$\begin{array}{c}\text { Identification } \\
\text { based on } \\
\text { nucleotide sequence } \\
\text { homology }\end{array}$} & \multicolumn{7}{|c|}{ Nucleotide sequence homology (\%) } \\
\hline & & & Reference strain & $\begin{array}{l}18 \mathrm{~S} \\
\mathrm{rDNA}\end{array}$ & ITS1 & $\begin{array}{l}5.8 \mathrm{~S} \\
\mathrm{rDNA}\end{array}$ & $\begin{array}{l}28 \mathrm{~S} \\
\mathrm{rDNA}\end{array}$ & $\beta-t u b$ & lys 2 \\
\hline \multirow{3}{*}{ Co-1 } & \multirow{3}{*}{ F. verticillioides ${ }^{\mathrm{b}}$} & \multirow{3}{*}{$\begin{array}{c}28 S \text { rDNA, } \\
\rightarrow F . \text { verticillioides }{ }^{\mathrm{b}} \\
\quad \text { b-tub, lys } 2 \\
\rightarrow \text { F. verticillioides }\end{array}$} & $\begin{array}{l}F . \text { verticillioides }^{\mathrm{b}} \\
\left(F . \text { verticillioides }^{\mathrm{c}}\right) \\
\quad \text { CBS576.78 }\end{array}$ & 100.00 & 100.00 & 100.00 & 100.00 & 100.00 & 100.00 \\
\hline & & & $\begin{array}{c}F . \text { proliferatum }^{\mathrm{b}} \\
(\text { F. phyllophilum }) \\
\text { CBS216.76 }\end{array}$ & 100.00 & 100.00 & 100.00 & 99.57 & 98.64 & 97.32 \\
\hline & & & $\begin{array}{l}\text { F. verticillioides } \\
\text { (F. thapsinum }) \\
\text { CBS100312 }\end{array}$ & 99.80 & 100.00 & 100.00 & 100.00 & 97.95 & 97.17 \\
\hline \multirow{4}{*}{$\mathrm{Co}-2$} & \multirow{4}{*}{ F. subglutinans ${ }^{\mathrm{b}}$} & \multirow{4}{*}{$\begin{array}{c}\beta-t u b, \text { lys } 2 \\
\rightarrow F . \text { subglutinans }\end{array}$} & $\begin{array}{c}\text { F. subglutinans }{ }^{\mathrm{b}} \\
\left(F . \text { subglutinans }^{\mathrm{c}}\right) \\
\text { ATCC } 38016\end{array}$ & 100.00 & 100.00 & 100.00 & 100.00 & 100.00 & 100.00 \\
\hline & & & $\begin{array}{l}\text { F. oxysporum } \\
\text { MAFF240304 }\end{array}$ & 100.00 & 99.17 & 100.00 & 99.35 & 97.44 & 94.72 \\
\hline & & & $\begin{array}{l}\text { F. oxysporum } \\
\text { MAFF } 240321\end{array}$ & 100.00 & 99.17 & 100.00 & 99.35 & 97.44 & 94.72 \\
\hline & & & $\begin{array}{l}\text { F. subglutinans }{ }^{\mathrm{b}} \\
\quad \text { (F. sacchari) } \\
\text { MAFF } 235376\end{array}$ & 100.00 & 99.17 & 100.00 & 100.00 & 95.90 & 95.17 \\
\hline \multirow{4}{*}{ Ch-1 } & \multirow{4}{*}{ F. spotrichiodes } & \multirow{4}{*}{$\begin{array}{c}28 S \text { rDNA, } \\
\beta \text {-tub, lys } 2 \\
\rightarrow \text { F. sporotrichioides }\end{array}$} & $\begin{array}{c}\text { F. sporotrichioides } \\
\text { ATCC34914 }\end{array}$ & 100.00 & 100.00 & 100.00 & 100.00 & 100.00 & 99.80 \\
\hline & & & $\begin{array}{c}\text { F. sporotrichioides } \\
\text { CBS119839 }\end{array}$ & 100.00 & 100.00 & 100.00 & 100.00 & 100.00 & 99.80 \\
\hline & & & $\begin{array}{c}F . \text { sporotrichioides } \\
\text { MAFF236639 }\end{array}$ & 100.00 & 100.00 & 100.00 & 100.00 & 100.00 & 99.80 \\
\hline & & & $\begin{array}{l}\text { F. langsethiae } \\
\text { CBS113234 }\end{array}$ & 100.00 & 100.00 & 100.00 & 100.00 & 99.15 & 99.39 \\
\hline \multirow{3}{*}{ Eg-1 } & \multirow{3}{*}{ F. tricinctum } & \multirow{3}{*}{$\begin{aligned} & 28 S \text { rDNA, } \\
& \beta \text {-tub, lys } 2 \\
& \rightarrow \text { F. tricinctum }\end{aligned}$} & $\begin{array}{l}F . \text { tricinctum } \\
\text { MAFF } 235551\end{array}$ & 100.00 & 100.00 & 100.00 & 100.00 & 100.00 & - \\
\hline & & & $\begin{array}{l}\text { F. tricinctum } \\
\text { ATCC } 38183\end{array}$ & 100.00 & 100.00 & 100.00 & 100.00 & 100.00 & - \\
\hline & & & $\begin{array}{l}\text { F. avenaceum } \\
\text { MAFF } 239206\end{array}$ & 100.00 & 100.00 & 100.00 & 100.00 & 97.95 & - \\
\hline \multirow{3}{*}{ Gmi-1 } & \multirow{3}{*}{$F$. nivale } & \multirow{3}{*}{$\begin{array}{l}28 S \text { rDNA, } \\
\quad \beta-t u b \\
\rightarrow F . \text { nivale }\end{array}$} & $\begin{array}{c}\text { F. nivale } \\
\text { MAFF236681 }\end{array}$ & 99.80 & 83.76 & 100.00 & 98.75 & 91.98 & - \\
\hline & & & $\begin{array}{l}\text { F. nivale } \\
\text { CBS116205 }\end{array}$ & 99.80 & 84.62 & 100.00 & 98.70 & 91.81 & - \\
\hline & & & $\begin{array}{l}\text { F. dimerum } \\
\text { CBS632.76 }\end{array}$ & 96.10 & 62.60 & 96.23 & 93.31 & 91.30 & - \\
\hline \multirow{4}{*}{ Gr-1 } & \multirow{4}{*}{ F. proliferatum } & \multirow{4}{*}{$\begin{array}{l}\text { ITS } 1, \beta \text {-tub, lys } 2 \\
\rightarrow F . \text { proliferatum }\end{array}$} & $\begin{array}{c}F . \text { proliferatum } \\
\left(F . \text { proliferatum }^{c}\right) \\
\text { MAFF } 238035\end{array}$ & 100.00 & 100.00 & 100.00 & 100.00 & 99.90 & 100.00 \\
\hline & & & $\begin{array}{l}\text { F. proliferatum } \\
\text { (F. fujikuroi) } \\
\text { MAFF } 237651\end{array}$ & 100.00 & 100.00 & 100.00 & 100.00 & 99.49 & 98.93 \\
\hline & & & $\begin{array}{l}\text { F. subglutinans } \\
\text { (F. sacchari) } \\
\text { MAFF } 235376\end{array}$ & 100.00 & 99.17 & 100.00 & 100.00 & 96.76 & 97.32 \\
\hline & & & $\begin{array}{c}\text { F. proliferatum } \\
\text { (F. phyllophilum) } \\
\text { CBS } 216.76\end{array}$ & 100.00 & 100.00 & 100.00 & 99.57 & 97.10 & 96.24 \\
\hline
\end{tabular}


Table 3. Continued

\begin{tabular}{|c|c|c|c|c|c|c|c|c|c|}
\hline \multirow{2}{*}{ Isolate } & \multirow{2}{*}{$\begin{array}{l}\text { Identification } \\
\text { based on } \\
\text { morphological } \\
\text { methods }^{\mathrm{a}}\end{array}$} & \multirow{2}{*}{$\begin{array}{c}\text { Identification } \\
\text { based on } \\
\text { nucleotide sequence } \\
\text { homology }\end{array}$} & \multicolumn{7}{|c|}{ Nucleotide sequence homology (\%) } \\
\hline & & & Reference strain & $\begin{array}{l}18 \mathrm{~S} \\
\mathrm{rDNA}\end{array}$ & ITS1 & $\begin{array}{c}5.8 \mathrm{~S} \\
\mathrm{rDNA}\end{array}$ & $\begin{array}{c}28 \mathrm{~S} \\
\mathrm{rDNA}\end{array}$ & $\beta-t u b$ & lys 2 \\
\hline \multirow{3}{*}{ Jp-1 } & \multirow{3}{*}{ F. semitectum } & \multirow{3}{*}{$\begin{array}{l}\text { ITS1, } \beta \text {-tub, lys } 2 \\
\rightarrow F \text {. semitectum }\end{array}$} & $\begin{array}{l}\text { F. semitectum } \\
\text { MAFF } 236521\end{array}$ & 100.00 & 100.00 & 100.00 & 100.00 & 100.00 & 100.00 \\
\hline & & & $\begin{array}{c}\text { F. equiseti } \\
\text { MAFF236434 }\end{array}$ & 100.00 & 99.17 & 100.00 & 100.00 & 98.81 & 92.01 \\
\hline & & & $\begin{array}{c}F . \text { equiseti } \\
\text { MAFF236723 }\end{array}$ & 100.00 & 99.18 & 98.73 & 100.00 & 98.29 & 93.44 \\
\hline \multirow{3}{*}{ Ma-1 } & \multirow{3}{*}{ F. semitectum } & \multirow{3}{*}{$\begin{array}{l}\text { ITS1, } \beta \text {-tub, lys } 2 \\
\rightarrow F \text {. semitectum }\end{array}$} & $\begin{array}{l}\text { F. semitectum } \\
\text { MAFF } 236521\end{array}$ & 100.00 & 100.00 & 100.00 & 100.00 & 100.00 & 100.00 \\
\hline & & & $\begin{array}{c}\text { F. equiseti } \\
\text { MAFF236434 }\end{array}$ & 100.00 & 99.17 & 100.00 & 100.00 & 98.81 & 92.01 \\
\hline & & & $\begin{array}{c}\text { F. equiseti } \\
\text { MAFF236723 }\end{array}$ & 100.00 & 99.18 & 98.73 & 100.00 & 98.29 & 93.44 \\
\hline \multirow{3}{*}{ Ma-2 } & \multirow{3}{*}{ F. equiseti } & \multirow{3}{*}{$\begin{array}{c}\text { ITS1 } \\
\rightarrow \text { F. semitectum } \\
\beta \text {-tub, lys } 2 \\
\rightarrow \text { F. equiseti }\end{array}$} & $\begin{array}{c}\text { F. equiseti } \\
\text { MAFF236434 }\end{array}$ & 100.00 & 99.17 & 100.00 & 100.00 & 98.98 & 93.65 \\
\hline & & & $\begin{array}{l}\text { F. semitectum } \\
\text { MAFF } 236521\end{array}$ & 100.00 & 100.00 & 100.00 & 100.00 & 98.81 & 91.80 \\
\hline & & & $\begin{array}{c}\text { F. equiseti } \\
\text { MAFF236723 }\end{array}$ & 100.00 & 99.18 & 98.73 & 100.00 & 98.81 & 92.62 \\
\hline \multirow{3}{*}{ Oa-1 } & \multirow{3}{*}{ F. verticillioides ${ }^{\mathrm{b}}$} & \multirow{3}{*}{$\begin{array}{c}\quad 28 S \text { rDNA, } \\
\rightarrow F . \text { verticillioides }^{\mathrm{b}} \\
\quad \text { b-tub, lys } 2 \\
\rightarrow \text { F. verticillioides }\end{array}$} & $\begin{array}{l}F . \text { verticillioides }^{\mathrm{b}} \\
\left(F . \text { verticillioides }^{\mathrm{c}}\right) \\
\quad \text { CBS576.78 }\end{array}$ & 100.00 & 100.00 & 100.00 & 100.00 & 99.83 & 100.00 \\
\hline & & & $\begin{array}{c}F . \text { proliferatum }^{\mathrm{b}} \\
(F . \text { phyllophilum }) \\
\text { CBS } 216.76\end{array}$ & 100.00 & 100.00 & 100.00 & 99.57 & 98.81 & 97.32 \\
\hline & & & $\begin{array}{c}\text { F. verticillioides } \\
\text { (F. thapsinum) } \\
\text { CBS100312 }\end{array}$ & 99.80 & 100.00 & 100.00 & 99.57 & 98.12 & 97.10 \\
\hline \multirow{3}{*}{ Oa-2 } & \multirow{3}{*}{ F. semitectum } & \multirow{3}{*}{$\begin{array}{l}\text { ITS1, } \beta \text {-tub, lys } 2 \\
\rightarrow F . \text { semitectum }\end{array}$} & $\begin{array}{l}\text { F. semitectum } \\
\text { MAFF } 236521\end{array}$ & 100.00 & 100.00 & 100.00 & 100.00 & 99.66 & 98.77 \\
\hline & & & $\begin{array}{c}\text { F. equiseti } \\
\text { MAFF236434 }\end{array}$ & 100.00 & 99.17 & 100.00 & 100.00 & 98.64 & 91.80 \\
\hline & & & $\begin{array}{c}\text { F. equiseti } \\
\text { MAFF } 236723\end{array}$ & 100.00 & 99.17 & 98.73 & 100.00 & 99.15 & 92.62 \\
\hline \multirow{3}{*}{ Po-1 } & \multirow{3}{*}{ F. oxysporum } & \multirow{3}{*}{$\begin{array}{l}\text { ITS1, } 28 \mathrm{~S} \text { rDNA, } \\
\beta \text {-tub, lys } 2 \\
\rightarrow \text { F. oxysporum }\end{array}$} & $\begin{array}{l}\text { F. oxysporum } \\
\text { MAFF } 240304\end{array}$ & 100.00 & 100.00 & 100.00 & 99.60 & 97.78 & 97.00 \\
\hline & & & $\begin{array}{l}\text { F. oxysporum } \\
\text { MAFF240321 }\end{array}$ & 100.00 & 100.00 & 100.00 & 99.60 & 97.78 & 97.00 \\
\hline & & & $\begin{array}{l}F . \text { proliferatum } \\
\text { CBS216.76 }\end{array}$ & 100.00 & 99.17 & 100.00 & 99.30 & 97.35 & 96.00 \\
\hline \multirow{4}{*}{ So-1 } & \multirow{4}{*}{ F. solani } & \multirow{4}{*}{$\begin{array}{l}28 S \text { rDNA, } \\
\beta \text {-tub, lys } 2 \\
\rightarrow F \text {. solani }\end{array}$} & $\begin{array}{c}\text { F. solani } \\
\text { NBRC8505 }\end{array}$ & 100.00 & 97.52 & 100.00 & 99.57 & 98.12 & - \\
\hline & & & $\begin{array}{c}\text { F. solani } \\
\text { MAFF238538 }\end{array}$ & 100.00 & 93.33 & 100.00 & 99.57 & 97.10 & - \\
\hline & & & $\begin{array}{c}\text { F. solani } \\
\text { MAFF } 239038\end{array}$ & 99.40 & 90.91 & 98.11 & 98.27 & 94.37 & - \\
\hline & & & $\begin{array}{l}\text { F. dimerum } \\
\text { MAFF237465 }\end{array}$ & 99.60 & 71.05 & 98.74 & 97.41 & 91.98 & - \\
\hline
\end{tabular}




\begin{tabular}{|c|c|c|c|c|c|c|c|c|c|}
\hline \multirow{2}{*}{ Isolate } & \multirow{2}{*}{$\begin{array}{l}\text { Identification } \\
\text { based on } \\
\text { morphological } \\
\text { methods }^{\mathrm{a}}\end{array}$} & \multirow{2}{*}{$\begin{array}{c}\text { Identification } \\
\text { based on } \\
\text { nucleotide sequence } \\
\text { homology }\end{array}$} & \multicolumn{7}{|c|}{ Nucleotide sequence homology (\%) } \\
\hline & & & Reference strain & $\begin{array}{l}18 \mathrm{~S} \\
\mathrm{rDNA}\end{array}$ & ITS1 & $\begin{array}{l}5.8 \mathrm{~S} \\
\mathrm{rDNA}\end{array}$ & $\begin{array}{l}28 \mathrm{~S} \\
\mathrm{rDNA}\end{array}$ & $\beta-t u b$ & lys 2 \\
\hline \multirow{4}{*}{ To-1 } & \multirow{4}{*}{ F. proliferatum ${ }^{\mathrm{b}}$} & \multirow{4}{*}{$\begin{array}{l}\text { ITS1, } \beta \text {-tub, lys } 2 \\
\rightarrow F . \text { proliferatum }^{\mathrm{b}}\end{array}$} & $\begin{array}{l}\text { F. proliferatum } \\
\text { (F. fujikuroi) } \\
\text { MAFF } 237651\end{array}$ & 100.00 & 100.00 & 100.00 & 100.00 & 100.00 & 99.82 \\
\hline & & & $\begin{array}{c}F . \text { proliferatum } \\
\left(F . \text { proliferatum }^{\mathrm{C}}\right) \\
\text { MAFF } 238035\end{array}$ & 100.00 & 100.00 & 100.00 & 100.00 & 99.13 & 99.10 \\
\hline & & & $\begin{array}{l}\text { F. proliferatum } \\
\text { (F. phyllophilum) } \\
\text { CBS216.76 }\end{array}$ & 100.00 & 100.00 & 100.00 & 99.57 & 96.93 & 96.10 \\
\hline & & & $\begin{array}{l}\text { F. oxysporum } \\
\text { MAFF240304 }\end{array}$ & 100.00 & 99.17 & 100.00 & 99.35 & 96.76 & 94.70 \\
\hline
\end{tabular}

\footnotetext{
${ }^{a}$ Nelson, et al. Fusarium species: An illustrated manual for identification, 1983.

${ }^{\mathrm{b}}$ sensu lato.

${ }^{\mathrm{c}}$ sensu strict.

The grey box indicates that the nucleotide sequence homology leaded to misidentification.

The open box indicates that the nucleotide sequence homology leaded to accurate identification.

Species in parenthesis is re-identified by nucleotide sequence homology in the new taxonomic systems.
}

カーであると言える。しかし，今回供試した19菌株中 4 菌株でPCRでの遺伝子増幅が見られず，同定が不可能 であった.lys2ではPCRでの遺伝子増幅が見られな かった菌種は以前の筆者らの研究に扔いても報告されて 抢り ${ }^{10)}$, 系統特異的にlys 2 の塩基置換速度がさらに加 速しているためと考えられる。また，lys2で菌株Ba-3 の同定を試みた際には，F. equiseti MAFF236434 と最 もホモロジーが高いことから F. equisetiと同定された. しかし, 形態学的手法による同定結果からは, 菌株 Ba-3は小型分生子を産出しないこと, 分生子形成様式 はpolyphialideが観察されるなどの特徵を有し, F. equiseti 明確に否定され，F. semitectumと同定された。 ITS1におけるMa-2の場合と同様に同定結果を総合的に 判断すると, 本菌株はF. semitectumであり, lys2 はこ の場合誤同定を起こしたものと考えられた。 $l y s 2$ を $F$. equiseti 抢よびF. semitectum 分離株の同定に用いる際に は注意が必要である。

$\beta$-tubでは, すべての分離株で同定が可能であった. 本遺伝子座はFusarium 属菌分離株の同定に適したマー カーであることがすでに示されているが10), species complex 形成する菌種の分離株であっても十分に識別 が可能であること，抢よび他の遺伝子座と異なり，誤同 定が起こらなかったことが確認された.

本研究の結果から, Fusarium 属の species complex 形成するような互いに極近縁な菌種を，最も高い相同性 を示した菌種を参照し正確に同定するための遺伝子指標 としては, 従来広く用いられてきたリボゾーム関連遺伝 子群や, 以前の筆者らの研究に打いて最も速い塩基置換 速度をもち優れたマーカーであることが示唆されたlys 2 よりも， $\beta$-tubが適するということが明らかとなった. ただし， $\beta$-tubを用いた場合でも，F. equiseti押よびF. oxysporum な゙塩基配列相同率の差が $1.0 \%$ 以下程度と 小さい場合もあり高いシークエンス精度が求められ，実 験的な操作による誤同定が起こる場合もあると考えられ る. そのため, 形態学的指標による同定も合わせて行う 必要がある。

なお，遺伝子塩基配列ホモロジーを指標とした真菌分 離株の同定を行う際には, 対象群についての分類学的な 知識に基づいて検索結果の解䣋を行い, 適正な判断を行 うことが必要不可欠である。1990年代以降, Gibberella fujikuroi species complexに含まれる分類群に新たな菌 種名が提唱された3).これらの菌種は形態学的指標に基 づいた場合非常に区別し難く ${ }^{3)}$, 本研究で参照した Nelson $ら^{4)}$ の分類体系においては別種として扱われてはい なかったが，その後交配集団拧よび分子生物学的な解析 結果を根拠として，この新たな菌種名が認知されつつあ る.これに基づくと,F. subglutinans MAFF235376は F. sacchari, F. proliferatum MAFF237651は F. fujikuroi, F. proliferatum CBS216.76は $F$. phyllophilum, $F$. verticillioides CBS100312はF. thapsinum とそれぞれ再 同定され(Table 3)， $\beta$-tubによれば，分離株Ba-2, Ba-4, Co-2, Gr-1 およびTo-1で示された(Table 3)ように，分 離株の同定もこのレベルまでの識別が可能であることが 明らかとなった. 本研究では, 現在広く用いられる形態 学的指標を用いた伝統的な分類体系による菌種名を用い たが，同定目的に応じて適した菌種名を選択する必要が ある。

遺伝子塩基配列ホモロジー検索による同定を行う際に は, 複数の既知の菌種と非常に高いホモロジーを示し 1 菌種に同定できない, または, 既知のいずれの菌種にも 適合せず同定が不可能など, 確からしい同定が不可能で ある場合がしばしば生じる，その原因として，デー夕 
ベース登録配列の多様性が低く近縁種を識別するための 情報を有していない，また，登録されている菌種や種内 集団にかぎりがあることなどが挙げられる，前者の問題 は，本研究によってFusarium 属菌の多くの菌種に属す る分離株について適したマーカーとなることが示された $\beta-t u b$ を用いれば，おおよその解決が可能であると考え られる。しかし, 後者の問題については, 本研究で作製 したデータベースにも収録されていない菌種および種内 集団が存在するため，可能なかぎりこれらのデータを データベースに加えることが必要不可欠であると考えら れる．以上の点について改善を行い，すべてのFusarium属菌分離株の同定にも適したデータベースの作製を 行うことが今後の検討課題であろう.

謝辞

本研究は厚生労働科学研究費補助金を受け実施され た

\section{文献}

1) Azor, M., Gene, J., Cano, J., et al.: Less-frequent Fusarium species of clinical interest: correlation between morphological and molecular identification and antifungal susceptibility. J. Clin. Microbiol., 47, 1463-1468 (2009).

2) Guadet, J., Julien, J., Lafay, J. F., et al.: Phylogeny of some Fusarium species, as determined by large-subunit rRNA sequence comparison. Molecular Biology and Evolution, 6, 227-242 (1989).

3) Leslie, J. F.: Gibberella fujikuroi: available populations and variable traints. Can. J. Bot., 73, S282-S291 (1995).
4) Nelson, P. E., Toussoun, T. A. and Marasas, W. F. O.: Fusarium species: An illustrated manual for identification. The Pennsylvania State University Press, Univercity Park (1983)

5) O'donnell, K., Sutton, D. A., Rinaldi, M. G., et al.: Internet-accessible DNA sequence database for identifying fusaria from human and animal infections. J. Clin. Microbiol., 48, 3708-3718 (2010).

6) Park, B., Park, J., Cheong, K. C., et al.: Cyber infrastructure for Fusarium: three integrated platforms supporting strain identification, phylogenetics, comparative genomics and knowledge sharing. Nucleic Acids Res., 39, D640-D646 (2011)

7) Pitt, J. I., Hocking, A. D.: Fungi and food spoilage. 3rd ed. Springer, Berlin (2009).

8) Tamura, K., Dudley, J., Nei, M., et al.: MEGA4: Molecular Evolutionary Genetics Analysis (MEGA) software version 4.0. Molecular Biology and Evolution, 24, 15961599 (2007).

9) Watanabe, M., Lee, K., Goto, K., et al.: Rapid and effective DNA extraction method with bead grinding for a large amount of fungal DNA. J. Food. Prot., 73, 1077-1084 (2010).

10) Watanabe, M., Yonezawa, T., Lee, K., et al.: Evaluation of genetic markers for identifying isolates of the species of the genus Fusarium. J. Sci. Food. Agric., 91, 2500-2504 (2011).

11) Watanabe, M., Yonezawa, T., Lee, K. I., et al.: Molecular phylogeny of the higher and lower taxonomy of the Fusarium genus and differences in the evolutionary histories of multiple genes. BMC Evol. Biol., 11, 322 (2011). 